\title{
Factors affecting motivation of academic staff at nursing faculties
}

\author{
Hanaa Esmail Sabra*1, Nahed Shawkat Abo-Elmagd ${ }^{2}$ \\ ${ }^{1}$ Faculty of Nursing, South Valley University, Quena, Egypt \\ ${ }^{2}$ Faculty of Nursing, Assiut University, Assiut, Egypt
}

Received: July 31, 2017

DOI: $10.5430 /$ jnep.v8n3p80
Accepted: October 15, $2017 \quad$ Online Published: November 16, 2017

URL: https://doi.org/10.5430/jnep.v8n3p80

\begin{abstract}
Objective: This study aims to examine the factors that affecting motivation of academic staff at Faculties of Nursing at Assiut, Sohag and Quena Universities.

Methods: A descriptive comparative design was used in the present study. Subjects of the study were all available academic staff who agreed to participate in the study (240). Tool of the study: A self-administered questionnaire was used for data collection it consisted of two parts: The first part included the personal characteristics of academic staff. The second part-Questionnaire of the factors that affecting motivation of academic staff which was adapted from Alam \& Farid \& Shaheen and colleagues contained 52 items.

Results: The findings of the present study showed that the first factor positively motivate the academic staff to teach was self-confidence, followed by choice of teaching staff for their profession. While, the first factor negatively affecting the motivation of the academic staff to teach was anxiety in classroom, followed by examination stress and rewards.

Conclusions: The factors positively motivate the academic staff to teach were self-confidence, choice of teaching staff for their profession, and relation of teachers with their colleagues. While, the factors negatively affecting the motivation of the academic staff to teach were anxiety in classroom, examination stress and rewards, socio-economic status of teaching staff, and administration polices. There were statistically significant differences and negative relation between socio-economic status, anxiety in classroom, and academic staff's years of experience while, there were statistically significant differences and positive relation between self-confidence, administrative policies and academic staff's years of experience. Recommendation: The academic staff must be acknowledged for their good performance and should be accompanied with improvement of their salary and academicians should not employ without a professional training by in-service training courses.
\end{abstract}

Key Words: Motivational factors, Academic staff, Nursing faculties

\section{INTRODUCTION}

The educational system is the corner stone for the development of any nations. Teachers are the backbone of the educational facilities, they are predictable to be the country constructers. ${ }^{[1]}$ The role of a teacher cannot be ignored in the bringing progress, prosperity and developmental process of a nation. By the advancement and rushing of growing through controlled, educationally sound and qualified competent academicians the constancy of the society will be attained. These organizations considered the improvement of their staff as a capital investment. ${ }^{[2]}$ The key role in the learning process is acting by the academic. The motivation of academic staff is very important as it directly affects the students. ${ }^{[3]}$

*Correspondence: Hanaa Esmail Sabra; Email: sabrahanaa_51@yahoo.com; Address: Faculty of Nursing, South Valley University, Quena, Egypt. 
Motivation is a basic psychological process. Along with perception, personality, attitudes, and learning, motivation is a very important element of behavior. Nevertheless, motivation is not the only explanation of behavior. It interacts with and acts in conjunction with other cognitive processes. Motivating is the management process of influencing behavior based on the knowledge of what make people tick. ${ }^{[4]}$

Huber $^{[5]}$ defined motivation as the process that arouses, energizes, directs, and sustains behavior and performance. That is the process of stimulating people to action and to achieve a desired task.

The efficiency performance is the master key for achievement the victory for any institutions. ${ }^{[6]}$ To effectively deliver on this objective, qualified and competent academicians are employed. The performance of academic staff is depending on the motivation not only a function of ability. ${ }^{[7]}$

$\operatorname{Razak}^{[8]}$ stated that collage staff hold the greatest significant position in any nation for they are the main channel of alteration of information. The worker performance is reliant on many organizational factors as: decision making, managerial, and administrative style those which must influence the personnel' motivation.

Bakay \& Huang ${ }^{[9]}$ mentioned that in hygienic motivation theory which was presented by Herzberg who explain that the employee will be internally motivated when their work and achievement connected to acknowledgment, responsibility and attainment, promotional chances, and career progression. The well-informed, motivated and committed staff can be the root to improve the educational level of the institutions. ${ }^{[1]}$

Motivation is crucial in harnessing effective performance of academic staff. The motivation of the academician to teach is influenced by several factors like; personal/social factors, classroom environment, Socio economic status, Student's behavior, examination stress, rewards/incentives, and self-confidence/personality of teacher, workload stress and administrative policies. ${ }^{[10]}$

\subsection{Significance of the study}

One of the most important problem that confronted the educational institutions are the academician motivation faced with the problems of motivational level of their academician, therefore the present study is designed to examine the factors that affecting motivation of academic staff at Faculties of Nursing at Assiut, Sohag and Quena Universities. Furthermore this research study can be helpful for educational institutions to recognize and realize the significance of these factors for promoting and enhancing motivational level of their academicians.

\subsection{Aim of the study}

This study aims to examine the factors that affecting motivation of the academic staff at Faculties of Nursing at Assiut, Sohag and Quena Universities.

\section{METHOD}

\subsection{Research questions}

(1) What are the factors responsible for positive or negative motivation of the academic staff?

(2) Are there relationship between personal characteristics and the factors affecting the motivation of academic staff?

(3) Is there a difference between the factors that affecting the motivation of academic staff in Assiut, Sohag, and Quena Universities?

\subsection{Research design}

A descriptive comparative design was used to examine factors that affecting the motivation of the academic staff at selected Nursing Faculties.

\subsubsection{Technical design}

The technical design for the study will include: Setting of the study, subjects and tools for data collection.

\section{1) Setting}

The study was conducted at Faculties of Nursing at Assiut, Sohag, and Quena Universities

\section{2) Subjects}

Subjects of the study were all available academic staff who agreed to participate in the study. They were 240 staff. classified as follow: 136 from Assiut, 50 from Sohag, and 54 from Quena University, represented all departments in the faculties (Nursing Administration, Pediatrics Nursing, Obstetrics \& Gynecological Nursing, General Medical Surgical Nursing, Critical care and Emergency, Community Health Nursing, Geriatric Nursing and Psychiatric Nursing).

\section{3) Tools of the study}

A self-administered questionnaire was used for data collection, and it consisted of two parts:

The first part: Personal characteristics of academic staff included setting, age, years of experience, marital status, occupation, and department.

The second part: Questionnaire of the factors that affecting motivation of the academic staff. The questionnaire used in this study is adapted with due acknowledgement from Alam $\&$ Farid $^{[10]}$ who conducted the research on factors affecting teachers motivation at secondary school Rawalpindi. The researchers added another item (administration policies) from 
Shaheen and colleagues. ${ }^{[1]}$ The modified questionnaire contain 52 items divided into seven subscale: choice of teaching staff for their profession (6 items), socio-economic status of teaching staff (10 items), self-confidence (13 items), anxiety in classroom (5 items), relation of teachers with their colleagues ( 3 items), examination stress and rewards ( 8 items) and administration policies ( 7 items), this Questionnaire was designed to examine the factors that affecting the motivation of the academic staff.

\section{4) Scoring system}

The responses for questionnaire were as follows: one grade was given when response yes and zero when the response was no. The scores of each item were summed up and then converted into a percent score. A score of $60 \%$ or higher was considered as "positive motive", and if less than $60 \%$ was considered "negative motive".

\section{5) Validity and reliability of the tool}

The study tool was translated into Arabic using the translate-re-translate process. The content validity of the questionnaire was assessed by a jury of 5 experts in the related field; the content validity index was 0.86 . The reliability was assessed using Cronbach alpha test to measure the internal consistency which yielded $(\alpha=0.89)$.

\subsubsection{Operational design}

This included the preparatory phase, pilot study, and data collection phase.

\section{A) Preparatory phase}

This phase took about three months from September to November 2016. The researchers spent this time in reviewing the available literature pertinent to the study topic. Additionally, Arabic translation and back translation of the study tool was done, and they were checked by experts for validation.

\section{B) Pilot study}

The pilot study were conducted on a sample of $10 \%$ of academic staff to test the applicability and reliability of the tool, and test the clarity of the designated questionnaire as well as to estimate the time needed to answer it. It also helped to test the feasibility and suitability of the study settings. Data obtained from the pilot were analyzed, no modifications were done.

\section{C) Data collection phase}

Data were collected from academic staff in the study setting at Faculty of Nursing at Assiut, Sohage and Quena Universities. The questionnaire sheet was self-administered filled, purpose and benefits of the study were explained to the participant, one of the researchers was present all the time to clarify any item that needed interpretation to the participant. The researchers informed the participant that their participation is voluntary; also, confidentiality and anonymity of subjects were assured by the researchers. This phase took data around half an hour for each participant to fill the forms. Two month was the entire duration for data collection phase.

\subsubsection{Administration design}

To carry out the study, the necessary approval was obtained from the deans of the faculties of nursing Assiut, Sohag, and Quena Universities. The researchers explained the aim of the study and requesting permission to use the premise for the collection of data.

\section{Ethical consideration}

- The study proposal takes agreement from the ethical committee in the faculty of nursing at Assiut University.

- An official permission to carry out the study was obtained from the responsible authorities.

- The researchers conducted a meeting with the Dean Faculty of nursing at Quena, Assiut and Sohag Universities to inform them about the objectives of the study and to gain the needed support and cooperation.

- Oral voluntary agreement was obtained from participant included in the study after explaining the purpose and the nature of the study, assure them that their participation will not be used against them in any way and have the right to refuse or to decide at any point to terminate their participation.

\subsubsection{Statistical design}

The collected data were thoroughly cleaned and then tabulated, analyzed, and interpreted. Data were entered and analyzed by SPSS 16 statistical analysis software package. Data were presented using descriptive statistics in the form of frequencies and percentages, means and standard deviations for qualitative variables. Quantitative continuance data were compared using $t$-test in case of comparisons between two groups. ANOVA test was used in case of comparisons among more than two groups, Mann-Whitney and Kruskal-Wallis Tests were also. Qualitative variables were compared using chi-square test. Statistical significance was considered at $p$ value $\leq .05$.

\section{RESULT}

Table 1 shows distribution of the study sample according to personal characteristics. The data in this table revealed that the academic staff were 240 , about $56.7 \%$ of them from Assiut University, about $22.5 \%$ of them from Quena University while about $20.8 \%$ of them from Sohag University, about 
$40.0 \%$ of them had their age less than 30 years, about $38.3 \%$ of them had less than 5 years of experience. It was noticed that more than half of them $(59.6 \%)$ were married while $40.4 \%$ were single. About $35.0 \%$ of them were demonstrator, $26.3 \%$ assistant lecturer, $25.4 \%$ lecturer, $11.3 \%$ assistant professor and $2.1 \%$ professor.

Table 1. Distribution of the study sample according to personal characteristics $(\mathrm{N}=240)$

\begin{tabular}{|c|c|c|}
\hline Items & No. $(n=240)$ & $\%$ \\
\hline \multicolumn{3}{|l|}{ Setting } \\
\hline Assiut & 136 & 56.7 \\
\hline Sohag & 50 & 20.8 \\
\hline Quena & 54 & 22.5 \\
\hline \multicolumn{3}{|l|}{ Age (years) } \\
\hline$<30$ & 96 & 40.0 \\
\hline $30-40$ & 68 & 28.3 \\
\hline$>40$ & 76 & 31.7 \\
\hline Mean \pm SD (Range) & \multicolumn{2}{|c|}{$35.17 \pm 9.11(22.0-55.0)$} \\
\hline \multicolumn{3}{|l|}{ Years of experience } \\
\hline$<5$ & 92 & 38.3 \\
\hline $5-10$ & 74 & 30.8 \\
\hline$>10$ & 74 & 30.8 \\
\hline Mean \pm SD (Range) & \multicolumn{2}{|c|}{$8.99 \pm 7.08(1.0-28.0)$} \\
\hline \multicolumn{3}{|l|}{ Marital status } \\
\hline Single & 97 & 40.4 \\
\hline Married & 143 & 59.6 \\
\hline \multicolumn{3}{|l|}{ Occupation } \\
\hline Demonstrator & 84 & 35.0 \\
\hline Assistant lecturer & 63 & 26.3 \\
\hline Lecturer & 61 & 25.4 \\
\hline Assistant professor & 27 & 11.3 \\
\hline Professor & 5 & 2.1 \\
\hline \multicolumn{3}{|l|}{ Department } \\
\hline Nursing Administration & 28 & 11.7 \\
\hline Pediatrics Nursing & 36 & 15.0 \\
\hline Obstetrics and Gynecological Nursing & 29 & 12.1 \\
\hline General Medical Surgical Nursing & 38 & 15.8 \\
\hline Critical care and Emergency & 30 & 12.5 \\
\hline Community Health Nursing & 32 & 13.3 \\
\hline Geriatrics Nursing & 17 & 7.1 \\
\hline Psychiatric Nursing & 30 & 12.5 \\
\hline
\end{tabular}

Figure 1 demonstrates percent of factors affecting motivation of academic staff. The data in this table illustrate that self-confidence is the first factor positively affecting the motivation of academic staff, followed by the choice of teaching staff for their profession, followed by relation of teachers staff with their colleagues $(90.8 \%, 81.7 \%, 76.7 \%$ respectively). While, the first factor negatively affecting the motivation of academic staff was anxiety in classroom, followed by the examination stress and rewards, followed by the Socioeconomic status of teaching staff $(89.2 \%, 72.5 \%, 66.7 \%$ respectively).

Table 2 reveals that there are statistically significant differences and negative relation between socio-economic status, anxiety in classroom, and years of experience $\left(p=.046^{*}, p\right.$ $=.014 *$ respectively), while there are statistically significant differences and positive relation between self-confidence, administrative policies and years of experience $(p=.004 *$, $p=.000 *$ respectively) between anxiety in classroom and years of experience $\left(p=.014^{*}\right)$. Also there is statistically significant differences and positive relation between selfconfidence, and age ( $\left.p=.016^{*}\right)$.

Table 3 illustrates that the highest mean score was related to self-confidence $(10.16 \pm 1.57,10.12 \pm 1.64$, and $8.79 \pm$ 2.32) for Sohag, Assiut, and Quena respectively while, the lowest mean score was related to anxiety in classroom $(0.52$ $\pm 0.71,0.65 \pm 1.03$, and $1.07 \pm 1.36$ ) for Sohag, Assiut and Quena, respectively. Also there are statistically significant differences in the following three items: self-confidence $(p=.014)$, examination stress and rewards $(p=.010)$ and administrative policies $(p=.035)$.

Table 4 shows mean and standard deviation of factors affecting motivation of academic staff according to age. The statistics in Table 4 explain that there is statistically significant differences in the only following two factors: socio-economic status of teaching staff $\left(p=.050^{*}\right)$ and self-confidence $(p=$ $.018 *)$.

Table 5 demonstrates mean and standard deviation of factors affecting motivation of academic staff according to years of experience. The data in this table reveals that there are statistically significant differences in the following three factors: self-confidence $\left(p=.013^{*}\right)$, anxiety in classroom $\left(p=.031^{*}\right)$ and administrative policies $\left(p=.000^{*}\right)$.

Table 6 shows mean and standard deviation of factors affecting motivation of academic staff according to marital status. The data in this table reveals that there are statistically significant differences in the following three factors: socio-economic status of teaching staff $(p=.001 *)$, anxiety in classroom $\left(p=.010^{*}\right)$ and administrative policies $(p=$ $.006 *)$.

Table 7 shows mean and standard deviation of factors affecting motivation of academic staff according to occupation. The data in this table reveals that there are statistically significant differences between the staff occupation and the factors that affecting their motivation; choice of teaching staff for their profession $(p=.027 *)$, Socio-economic status of teaching staff $\left(p=.039^{*}\right)$, Self-confidence $\left(p=.008^{*}\right)$ and Administrative policies $(p=.013)$. 


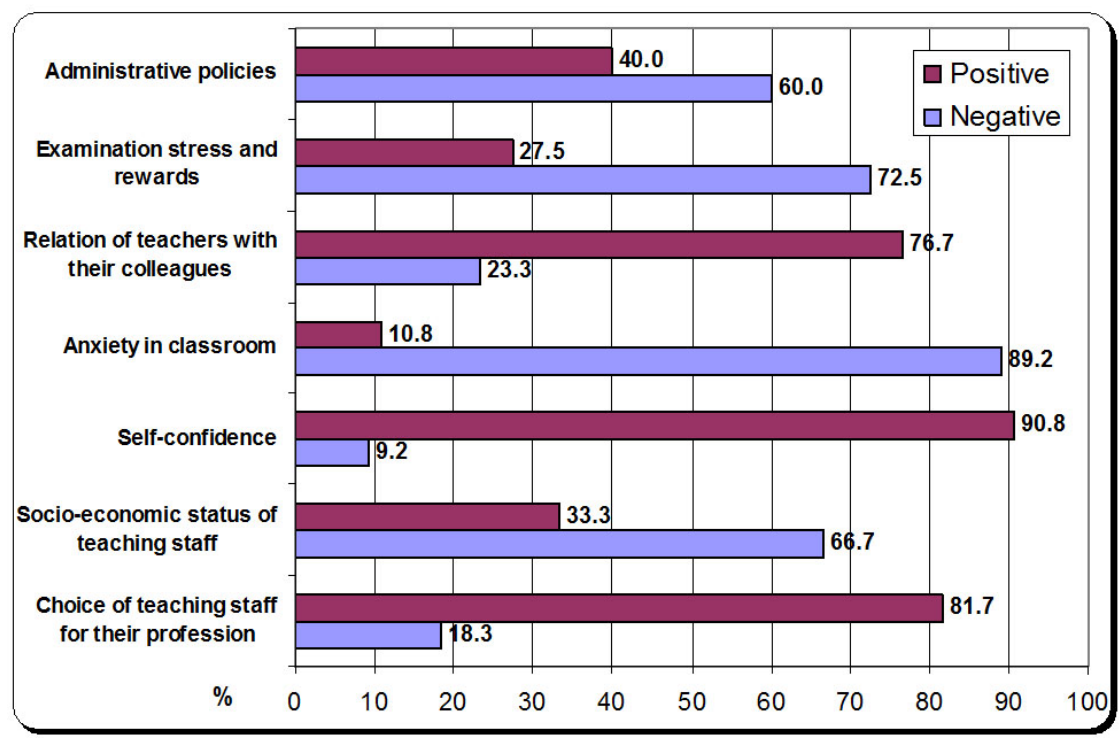

Figure 1. The percentage distribution of the factors affecting motivation of academic staff $(N=240)$

Table 2. Correlation between factors affecting motivation of academic staff, age and year of experience $(\mathrm{N}=240)$

\begin{tabular}{llllll}
\hline \multirow{2}{*}{ Items } & Age (years) & & & \multicolumn{2}{c}{ Years of experience } \\
\cline { 2 - 3 } \cline { 5 - 6 } & $\boldsymbol{r}$ & $\boldsymbol{p}$ & & $\boldsymbol{r}$ & $\boldsymbol{p}$ \\
\hline Choice of teaching staff for their profession & -0.065 & .481 & & 0.024 & .793 \\
Socio-economic status of teaching staff & -0.140 & .125 & & -0.182 & $.046^{*}$ \\
Self-confidence & 0.219 & $.016^{*}$ & & 0.262 & $.004^{*}$ \\
Anxiety in classroom & -0.134 & .142 & & -0.224 & $.014^{*}$ \\
Relation of teachers with their colleagues & -0.009 & .923 & & 0.045 & .621 \\
Examination stress and rewards & 0.140 & .127 & & 0.045 & .625 \\
Administrative policies & 0.131 & .151 & & 0.334 & $.000^{*}$ \\
\hline
\end{tabular}
$* p<.05$

Table 3. Comparison of mean and standard deviation for the factors affecting motivation of academic staff by setting $(\mathrm{N}=$ 240)

\begin{tabular}{|c|c|c|c|c|}
\hline \multirow{3}{*}{ Items } & \multicolumn{3}{|l|}{ Setting } & \multirow{3}{*}{$p$} \\
\hline & Assiut & Sohag & Quena & \\
\hline & Mean \pm SD & Mean \pm SD & Mean \pm SD & \\
\hline Choice of teaching staff for their profession & $4.34 \pm 1.39$ & $5.16 \pm 0.75$ & $4.54 \pm 1.45$ & .051 \\
\hline Socio-economic status of teaching staff & $5.74 \pm 2.25$ & $5.20 \pm 1.96$ & $5.64 \pm 2.44$ & .580 \\
\hline Self-confidence & $10.12 \pm 1.64$ & $10.16 \pm 1.57$ & $8.79 \pm 2.32$ & $.014^{*}$ \\
\hline Anxiety in classroom & $0.65 \pm 1.03$ & $0.52 \pm 0.71$ & $1.07 \pm 1.36$ & .222 \\
\hline Relation of teaching staff with their colleagues & $1.97 \pm 0.65$ & $2.08 \pm 0.70$ & $1.82 \pm 0.72$ & .439 \\
\hline Examination stress and rewards & $3.88 \pm 1.61$ & $2.96 \pm 1.24$ & $3.07 \pm 1.15$ & $.010^{*}$ \\
\hline Administrative policies & $3.24 \pm 2.43$ & $2.40 \pm 2.00$ & $1.89 \pm 1.95$ & $.035 *$ \\
\hline
\end{tabular}
* $p<.05$

\section{Discussion}

Academic staff of higher education institutions is reflected to be the key for education. They have played an important role in achieving the objectives of the institution. Well-motivated 84 teaching staff can build a national and international reputation for themselves and the university, and improve the ability of the university to attract more students, research funds. ${ }^{[8]}$

ISSN 1925-4040 E-ISSN 1925-4059 
Table 4. Comparison of mean and standard deviation for factors affecting motivation of academic staff according to age ( $\mathrm{N}$ $=240)$

\begin{tabular}{|c|c|c|c|c|}
\hline \multirow{3}{*}{ Items } & \multicolumn{3}{|l|}{ Age (years) } & \multirow{3}{*}{$p$} \\
\hline & $<30$ & $30-40$ & $>40$ & \\
\hline & Mean \pm SD & Mean \pm SD & Mean \pm SD & \\
\hline Choice of teaching staff for their profession & $4.71 \pm 1.27$ & $4.32 \pm 1.36$ & $4.56 \pm 1.37$ & .362 \\
\hline Socio-economic status of teaching staff & $6.19 \pm 2.14$ & $4.97 \pm 2.15$ & $5.44 \pm 2.28$ & $.050 *$ \\
\hline Self-confidence & $9.31 \pm 2.08$ & $9.74 \pm 1.75$ & $10.51 \pm 1.52$ & $.018^{*}$ \\
\hline Anxiety in classroom & $0.87 \pm 1.18$ & $0.74 \pm 1.14$ & $0.51 \pm 0.85$ & .280 \\
\hline Relation of teachers with their colleagues & $1.98 \pm 0.70$ & $1.91 \pm 0.62$ & $1.97 \pm 0.71$ & .855 \\
\hline Examination stress and rewards & $3.10 \pm 1.39$ & $3.82 \pm 1.57$ & $3.72 \pm 1.49$ & .057 \\
\hline Administrative policies & $2.23 \pm 2.08$ & $3.24 \pm 2.23$ & $2.97 \pm 2.54$ & .131 \\
\hline
\end{tabular}
$* p<.05$

Table 5. Comparison of mean and standard deviation for factors affecting motivation of academic staff according to years of experience $(\mathrm{N}=240)$

\begin{tabular}{|c|c|c|c|c|}
\hline \multirow{3}{*}{ Items } & \multicolumn{3}{|c|}{ Years of experience } & \multirow{3}{*}{$p$} \\
\hline & $<5$ & $5-10$ & $>10$ & \\
\hline & Mean \pm SD & Mean \pm SD & Mean \pm SD & \\
\hline Choice of teaching staff for their profession & $4.46 \pm 1.39$ & $4.65 \pm 1.25$ & $4.58 \pm 1.35$ & .816 \\
\hline Socio-economic status of teaching staff & $6.13 \pm 2.18$ & $5.51 \pm 2.26$ & $5.05 \pm 2.18$ & .100 \\
\hline Self-confidence & $9.20 \pm 2.23$ & $9.86 \pm 1.49$ & $10.53 \pm 1.50$ & $.013^{*}$ \\
\hline Anxiety in classroom & $1.02 \pm 1.27$ & $0.68 \pm 0.97$ & $0.39 \pm 0.79$ & $.031^{*}$ \\
\hline Relation of teachers with their colleagues & $1.98 \pm 0.61$ & $1.81 \pm 0.70$ & $2.08 \pm 0.71$ & .198 \\
\hline Examination stress and rewards & $3.33 \pm 1.46$ & $3.59 \pm 1.54$ & $3.63 \pm 1.51$ & .525 \\
\hline Administrative policies & $2.17 \pm 2.09$ & $2.03 \pm 2.02$ & $4.16 \pm 2.21$ & $.000^{*}$ \\
\hline
\end{tabular}

$* p<.05$

Table 6. Comparison of mean and standard deviation for factors affecting motivation of academic staff according to marital status $(\mathrm{N}=240)$

\begin{tabular}{|c|c|c|c|}
\hline \multirow{3}{*}{ Items } & \multicolumn{2}{|c|}{ Marital status } & \multirow{3}{*}{$p$} \\
\hline & Single & Married & \\
\hline & Mean \pm SD & Mean \pm SD & \\
\hline Choice of teaching staff for their profession & $4.39 \pm 1.53$ & $4.67 \pm 1.17$ & .633 \\
\hline Socio-economic status of teaching staff & $6.37 \pm 2.06$ & $5.08 \pm 2.21$ & $.001^{*}$ \\
\hline Self-confidence & $9.69 \pm 2.05$ & $9.90 \pm 1.76$ & .847 \\
\hline Anxiety in classroom & $1.06 \pm 1.30$ & $0.49 \pm 0.82$ & $.010^{*}$ \\
\hline Relation of teachers with their colleagues & $1.86 \pm 0.71$ & $2.03 \pm 0.65$ & .201 \\
\hline Examination stress and rewards & $3.63 \pm 1.38$ & $3.42 \pm 1.57$ & .344 \\
\hline Administrative policies & $2.08 \pm 2.26$ & $3.21 \pm 2.23$ & $.006 *$ \\
\hline
\end{tabular}

$* p<.05$

This study was conducted with the purpose of examining the factors that affecting motivation of the academic staff at Faculties of Nursing at Assiut, Sohag, and Quena Universities. The findings of the present study showed that the first factor positively motivate the academic staff to teach was

self-confidence, followed by choice of teaching staff for their profession, followed by relation of teachers staff with their colleagues respectively.

This finding was inconsistence with Osakwe ${ }^{[11]}$ who stated that the individuals are essentially motivated when their work 
linked with some factors, such as; recognition, responsibility and attainment, promotional chances, and career advancement. These findings were confirmed by Nadeem and colleagues ${ }^{[6]}$ who pointed out that the degree of provision that given by the professional relationship with peers, supervisors, and department head has an influence on their motivational level.

On other hand the findings of the present study were not accordance with Khan and Mansoor ${ }^{[12]}$ who found that the greatest important factors for the teaching staff motivation were the recognition and work itself. ${ }^{[13,14]}$

Table 7. Comparison of mean and standard deviation for factors affecting motivation of academic staff according to occupation $(\mathrm{N}=240)$

\begin{tabular}{|c|c|c|c|c|c|}
\hline \multirow{3}{*}{ Items } & \multicolumn{4}{|l|}{ Occupation } & \multirow{3}{*}{$p$} \\
\hline & Demonstrator & $\begin{array}{l}\text { Assistant } \\
\text { Lecturer }\end{array}$ & Lecturer & $\begin{array}{l}\text { Assistant } \\
\text { Professor/Professor }\end{array}$ & \\
\hline & Mean \pm SD & Mean \pm SD & Mean \pm SD & Mean \pm SD & \\
\hline Choice of teaching staff for their profession & $4.83 \pm 1.23$ & $4.23 \pm 1.34$ & $4.17 \pm 1.52$ & $5.18 \pm 0.64$ & $.027 *$ \\
\hline Socio-economic status of teaching staff & $6.21 \pm 2.12$ & $5.58 \pm 2.25$ & $4.75 \pm 2.26$ & $5.94 \pm 1.98$ & $.039 *$ \\
\hline Self-confidence & $9.33 \pm 2.16$ & $9.62 \pm 1.47$ & $9.94 \pm 1.66$ & $11.06 \pm 1.68$ & $.008^{*}$ \\
\hline Anxiety in classroom & $0.95 \pm 1.17$ & $0.65 \pm 1.02$ & $0.72 \pm 1.14$ & $0.24 \pm 0.56$ & .056 \\
\hline Relation of teachers with their colleagues & $1.95 \pm 0.62$ & $1.92 \pm 0.80$ & $1.89 \pm 0.71$ & $2.18 \pm 0.53$ & .497 \\
\hline Examination stress and rewards & $3.45 \pm 1.47$ & $3.35 \pm 1.41$ & $3.75 \pm 1.56$ & $3.35 \pm 1.62$ & .678 \\
\hline Administrative policies & $2.60 \pm 2.21$ & $2.23 \pm 2.12$ & $2.53 \pm 2.37$ & $4.41 \pm 2.06$ & $.013^{*}$ \\
\hline
\end{tabular}

$* p<.05$

The results of this study exposed that the first factor negatively affecting the motivation of the academic staff to teach was anxiety in classroom, followed by examination stress and rewards and, socio-economic status of teaching staff respectively. This might be due to that all faculty staff need to be well trained by the university to be well qualified as academic staff so they can handle the anxiety in classroom .

These findings were consistent with Buberwa ${ }^{[15]}$ who stated that there are factors that negatively influence the staff performance as: academician's moral standards, examination stress, and student power. In the same line Hagos and Abrha ${ }^{[16]}$ concluded from their research that the "salary" was the minimum motivating feature, and "achievement" was the maximum motivating feature. But the present study finding were not in agreement with the finding of Pattanayak ${ }^{[17]}$ who found that the routine work may be worsening within the deficiency of some aspect like pay, promotion, and certificates of appreciation while these aspect provoke more motivation if it was obtainable in relative with performance

The results of the current study showed that there were statistically significant differences and negative relation between socio-economic status, anxiety in classroom, and years of experience while, there were statistically significant differences and positive relation between self-confidence, administrative policies and years of experience .

These results of this study are in congruence with the find- ings reported by Basak and Govender ${ }^{[18]}$ who mentioned that many studies have been conducted, with the conclusion that there was a correlation between academic job satisfaction (which it is indicator of staff motivation) and several variables these include; policy and administration, supervision, salary, interpersonal relations, working conditions, achievement, age, recognition, tenure, the work itself, educational level, responsibility, teaching experience, and advancement. ${ }^{[19]}$

The present study revealed that there were statistically significant differences among the three universities Assiut, Sohag and Quena as regards to self-confidence, examination stress and rewards, and administrative policies. This may be due to that the three nursing faculties are not all alike. These findings were in agreement with Abo El-Magd \& Morsy ${ }^{[20]}$ who found in their study that governance behaviors at nursing colleges are not all alike, even though we can also assert that nursing colleges are not as a whole bureaucratic and managerial institutions portrayed in the literature.

The results of this study displayed that there were statistically significant differences between the staff occupation and the factors that affecting their motivation to teach as; choice of teaching staff for their profession, socio-economic status of teaching staff, self-confidence and administrative policies. This finding was consistent with Shaheen and colleagues ${ }^{[1]}$ who mentioned that respectable number of academic staff were unsatisfied with the placement policies and accountabil- 
ity system of the university but a maximum of them were finding career development chances by university administration.

The present study revealed that there were statistically significant differences between the staff occupation and the factors that affecting their motivation to teach like; choice of teaching staff for their profession, Socio-economic status of teaching staff, Self-confidence, and Administrative policies. This may be due to the results of the challenge that facing each category is different; lecture and assistant professor/professor facing the challenging of promotion, limited opportunities as far as funds and scholarships for Masters and $\mathrm{PhD}$ studies for academic staff, the recognition of best performers is also a challenge. While, demonstrator and assistant lecture facing the scarcity of teaching tools, fails to conduct training, workshops, and seminars all due to scarcity of funds.

This finding was supported with the MUCCoBS Up the Ladder Policy ${ }^{[21]}$ who found that the documentations revealed that promotion of an assistant lecturer required at least three years' experience of in service academic staff, Also in the same line MUCASA Minutes ${ }^{[22]}$ found out that, the university had no performance standards set by the university to recognize their efforts. Even the first of May prize for best performers is not available. Lastly, this was in the same line with Buberwa ${ }^{[15]}$ who found that lack of proper working tools is a challenge in many public universities due to meager budgets and this cause low staff motivation.

\section{Conclusions}

The following conclusions were drawn based on findings of the present study:

- The first factor positively motivate the academic staff to teach was self-confidence followed by choice of teaching staff for their profession followed by relation of academic staff with their colleagues. While, first factor negatively affecting the motivation of the academic staff to teach was anxiety in classroom followed by the examination stress and rewards followed by socio-economic status of teaching staff and finally followed by the administration polices.

- There were statistically significant differences and negative relation between socio-economic status, anxiety in classroom, and academic staff's years of experience while, there were statistically significant differences and positive relation between self-confidence, administrative policies and academic staff's years of experience.

- There were statistically significant differences among the three universities Assiut, Sohag and Quena as regards to self-confidence, examination stress and rewards, and administrative policies.

- There were statistically significant differences between the staff occupation and the factors that affecting their motivation to teach like; choice of teaching staff for their profession, Socio-economic status of teaching staff, Self-confidence, and Administrative policies.

\section{Recommendations}

Based on the study finding, it was recommended the following:

(1) The academic staff must be acknowledged for their good performance, and should be accompanied with improvement of their salary, rewards other fringe benefits.

(2) Academicians should not employ without a professional training by in-service training courses that will refresh and improve their teaching skills and performance.

(3) The aptitude tests should be designed, implemented and conducted at the time of the selection and employment of academicians. This will identify positive attitudes of academic staff towards teaching profession.

(4) The academic staff should be actively involved in all levels of decision-making to be aware of their faculty policies.

\section{CONFlicts OF InTEREST Disclosure}

The authors declare that there is no conflict of interest.

\section{REFERENCES}

[1] Shaheen I, A.Sajid M, Batool Q. Factors Affecting the Motivation of Academic Staff (A case study of University College Kotli, UAJ\&K). International Journal of Business and Management Invention. 2013.

[2] Tella A, Ayeni C, Popoola S. Work Motivation, Job Satisfaction, and Organizational Commitment of Library Personnel in Academic and
Research Libraries in Oyo State, Nigeria. Library Philosophy and Practice. 2007.

[3] Kayuni H, Tambulsai R. Teacher turnover in Malawi's Ministry of Education: Realities and Challenges. International Education Journal. 2007; 8(1): 89-99.

[4] Zhang X, Doug Davies. Factors that Motivate Academic Staff to Con- 
duct Research in Chinese Universities, Global Business and Social Science Research Conference, Beijing. 2011.

[5] Huber D. Leadership and Nursing Care Management. Philadelphia, WB. Saunders Co. 2000.

[6] Nadeem, et al. Teacher's Competencies and Factors Affecting the Performance of Female Teachers in Bahawalpur (Southern Punjab) Pakistan. International Journal of Business and Social Science. 2011.

[7] Nnko E. An Investigation of Job Satisfaction of Members of Academic Staff at MUCCoBS. Master's Dissertation. Mzumbe University: Unpublished. 2010.

[8] Razzak A. Factors Affecting the Effectiveness of Job Performance of Specialists Working In the Youth Care Centre at Helwan University. World Journal of Sport Sciences. 2011; 4(2): 116-125.

[9] Bakay A, Huang J. A conceptual Model of Motivational Antecedents of Job Outcomes and How Organizational Culture Moderates. 2010

[10] Alam T, Farid S. Factors Affecting Teachers Motivation. International Journal of Business and Social Science. 2011.

[11] Osakwe R. Factors Affecting Motivation and Job Satisfaction of Academic Staff of Universities in South-South Geopolitical Zone of Nigeria. International Education Studies; 2014.

[12] Khan M, Mansoor H. Factors Influencing Motivation Level of Academic Staff in Education Sector of Pakistan. Global Journal of Human Resource Management. 2013.

[13] Khan K, Farooq S, Ullah M. The Relationship between Rewards and Employee Motivation in Commercial Banks of Pakistan. Research Journal of International Studies. 2010.
[14] Rasheed M, Aslam H, Sarwar S. Motivational Issues for Teachers in Higher Education: A Critical Case of IUB. Journal of Management Research. 2010; 2(2). https://doi.org/10.5296/jmr.v2i2.3 49

[15] Buberwa E. Academic Staff Motivation in Tanzania Public Higher Learning Institutions: Unmasking the Intricacies and Experiences, European Journal of Business and Management. 2015.

[16] Hagos G, Abrha K. Study on factors Affecting Job Satisfaction in Mekelle University Academic staff at Adi-Haqi Campus. International Journal of Scientific and Research Publications. 2015

[17] Pattanayak B. Human Resource Management. India: Prentice Hall. 2012.

[18] Basak S, Govender D. Theoretical Framework of the Factors Affecting University Academics' Job Satisfaction. International Business \& Economics Research Journal. 2015.

[19] Adeel M, Khan I, Danial A, et al. Impact of HR Practices on Job Satisfaction of University Teacher: Evidence from Universities in Pakistan. Industrial Engineering Letters. 2011; 1(3): 10-17.

[20] Abo El-Magd N, Morsy S. Effect of Shared Governance on Nursing Faculty Staff's Commitment in Upper Egypt. Assiut Scientific Nursing Journal. 2015.

[21] MUCCoBS. Up the Ladder Policy, Moshi: MUCCoBS. 2013.

[22] MUCASA Meetings' Minutes. Moshi: MUCASA. 2014. 